\title{
Lectotypification and a new synonym in Palicourea (Rubiaceae)
}

\author{
Carla Y’ Gubáu Manão ${ }^{1}$, Roberto Lourenço Esteves ${ }^{2} \&$ Sebastião José da Silva Neto ${ }^{2}$ \\ ${ }^{1}$ Universidade do Estado do Rio de Janeiro, RJ, 20550-900, Brasil; carlaygm@gmail.com \\ ${ }^{2}$ Universidade do Estado do Rio de Janeiro, Instituto de Biologia Roberto Alcântara Gomes, Departamento de Biologia Vegetal, \\ Rua São Francisco Xavier 524, Maracanã, Rio de Janeiro, RJ, 20550-900, Brasil; esteves@uerj.gov.br; sseba@terra.com.br
}

\begin{abstract}
Y' Gubáu Manão, C., Lourenço Esteves, R. \& Da Silva Neto, S.J. 2016. Lectotypification and a new synonym in Palicourea Aubl. (Rubiaceae). Anales Jard. Bot. Madrid 73(1): e033.

Here we designate specimen no. 10424 from the Museu Nacional (R) as the lectotype of Palicourea rudgeoides (Müll. Arg.) Standl. [Psychotria rudgeoides Müll. Arg., basion.], and assign a new synonym for Palicourea fulgens (Müll. Arg.) Standl., Psychotria exannulata Müll. Arg., based on specimen no. 607125 from the Field Museum of Natural History (F).
\end{abstract}

Keywords: Brazil, Gentianales, Palicourea fulgens, Palicourea rudgeoides, Rubioideae, typification.

\section{INTRODUCTION}

Palicourea Aubl. is a neotropical genus (Taylor, 1997) with ca. 250 species in the world (Taylor \& Steyermark, 2004), of which 55 species, 6 subspecies, and 1 variety are found in Brazil (Zappi \& Taylor, 2010). The Brazilian species grow mostly in the understory of the Atlantic Forest ("Mata Atlântica") and the Amazon rainforest ("Floresta Amazônica"), but they are also found in the savannas ("Cerrado") and occasionally, although rarely, in the "campo-rupestre". Species in this genus are monoecious, with dichlamydeous, monoclinal, coloured flowers, grouped into terminal inflorescences.

\section{TAXONOMIC TREATMENT}

During taxonomic studies of Palicourea in Brazil, it was established that the lectotypification of the name Psychotria rudgeoides Müll. Arg. in Mart., Fl. Bras. 6(5): 463 (1881) was needed. For the lectotype designation, a search for original material was performed in order to find the best preserved and most representative specimens, according to the protologue and the International Code of Nomenclature (McNeill \& al., 2012). The search was made among the remaining original material of the taxon, available in high resolution digital format in JSTOR Plant Science (<http:// plants.jstor.org/>), Berlin Negatives collection (<http:// emuweb.fieldmuseum.org/botany/search_berlin.php $>$ ) and Muséum MNHN - National d'Histoire Naturelle (<http://coldb.mnhn.fr/>).

Palicourea rudgeoides (Müll. Arg.) Standl., Publ. Field Mus. Nat. Hist., Bot. Ser. 8: 381 (1931). Psychotria rudgeoides Müll.

\section{Resumen}

Y' Gubáu Manão, C., Lourenço Esteves, R. \& Da Silva Neto, S.J. 2016. Lectotipificación y nuevo sinónimo en Palicourea Aubl. (Rubiaceae). Anales Jard. Bot. Madrid 73(1): e033.

Se designa como lectotipo de Palicourea rudgeoides (Müll. Arg.) Standl. [Psychotria rudgeoides Müll. Arg., basión.] el espécimen n. ${ }^{\circ}$ 10424, conservado en el Museu Nacional (R) y, para Palicourea fulgens (Müll. Arg.) Standl., se asignó un nuevo sinónimo, Psychotria exannulata Müll. Arg., representado por el espécimen n. ${ }^{\circ} 607125$ conservado en el Field Museum of Natural History (F).

Palabras clave: Brasil, Gentianales, Palicourea fulgens, Palicourea rudgeoides, Rubioideae, tipificación.

Arg. in Mart., Fl. Bras. 6(5): 463 (1881). Uragoga rudgeiodes (Müll. Arg.) Kuntze, Revis. Gen. Pl. 2: 962 (1891). Palicourea melheana Jung-Mend., Hoehnea 18(2): 143-147 (1991).

TYPE: [Brazil.] Rio de Janeiro, A.F.M. Glaziou \#8747 (lectotype, here designated: R 10424!, Fig. 1; isolectotypes: G 301300!, G 300253!, K 471454!).

Botanischer Garten und Botanisches Museum BerlinDahlem (B) is the main depository for herbarium collections of A.F.M. Glaziou numbered between 3267 and 22770 (Urban, 1906). However, in 1943 the collection of the herbarium in Berlin was completely destroyed, as a result of the Second World War. Currently only the photo negative $n^{\circ} 628$ is available in the Field Museum of Natural History (F), corresponding to the holotype for Palicourea. In accordance to the Article 9.12. of the ICN, the lectotype R 10424 was selected among the existing isotypes. The herbarium of Museu Nacional da Universidade Federal do Rio de Janeiro (R) was cited as the main repository of duplicates from Glaziou collections in the XIXth century (Urban, 1906). This herbarium was the first to be founded in Brazil in 1831 and is well known for its historical collections, such as the nomenclatural types of Glaziou and Freire Allemão.

Palicourea fulgens (Müll. Arg.) Standl., Publ. Field Mus. Nat. Hist., Bot. Ser. 8: 380 (1931). Psychotria fulgens Müll. Arg. in Mart., Fl. Bras. 6(5): 257 (1881). Uragoga fulgens (Müll. Arg.) Kuntze, Revis. Gen. Pl. 2: 960 (1891).

TYPE: [Brazil.] Bahia, in silvis primitivis da Pernipe ad coloniam Leopoldinam, J.S. Blanchet \#1428 (holotype: G 436469!; isotypes: P 40018654!, G 436468!, P 4018653!, F 734076!, F 520727!, F 521012!, F 767022!). 


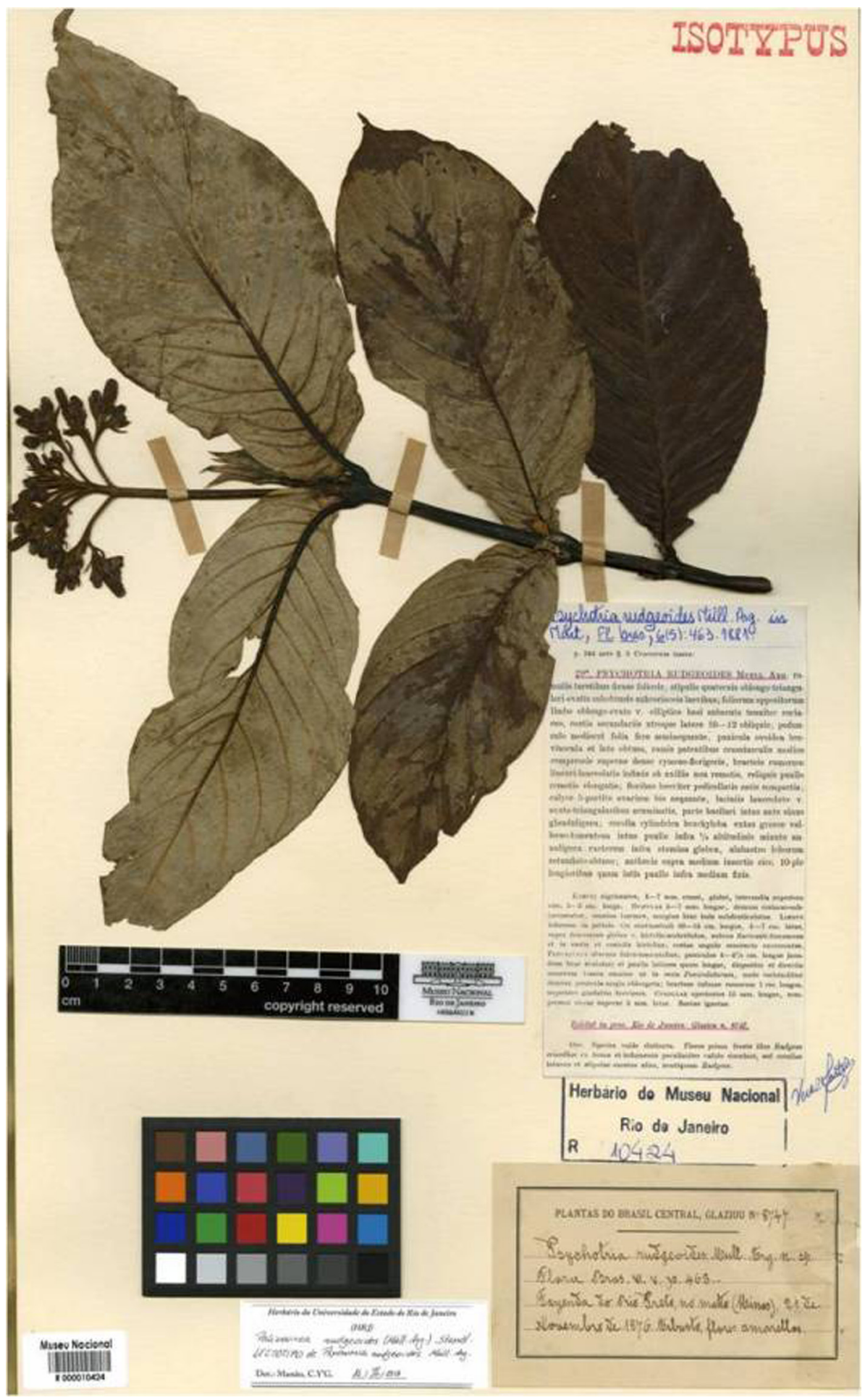

Fig. 1. Lectotype of Psychotria rudgeoides Müll. Arg. (R 10424).

Psychotria exannulata Müll. Arg. in Mart., Fl. Bras. 6(5): 257 (1881), syn. nov. Uragoga exannulata (Müll. Arg.) Kuntze, Revis. Gen. Pl. 2: 960 (1891).

TYPE: [Brazil.] Bahia, inter Campos et Vittoria. H.L. Sello \#225 (syntype: F 607125!, Fig. 2; specimens corresponding to Sello \#302 and \#384 were not located).

In addition to the new lectotypification of Psychotria rudgeoides, another nomenclatural novelty came to light during the study of Palicourea. According to the protologues of Psychotria exannulata Müll. Arg. in Mart., Fl. Bras. 6(5): 257 (1881) and Psychotria fulgens Müll. Arg. in Mart., Fl. Bras. 6(5): 257 (1881), J. Müller Argoviensis separated these two species mainly based on the shape of the inflorescence. Whereas the inflorescence had a panicle of corymbs in the first species, it is mostly arranged in a panicle of umbels in the second one. The confrontation of nomenclatural types and additional material by analyzing the diagnoses of both 


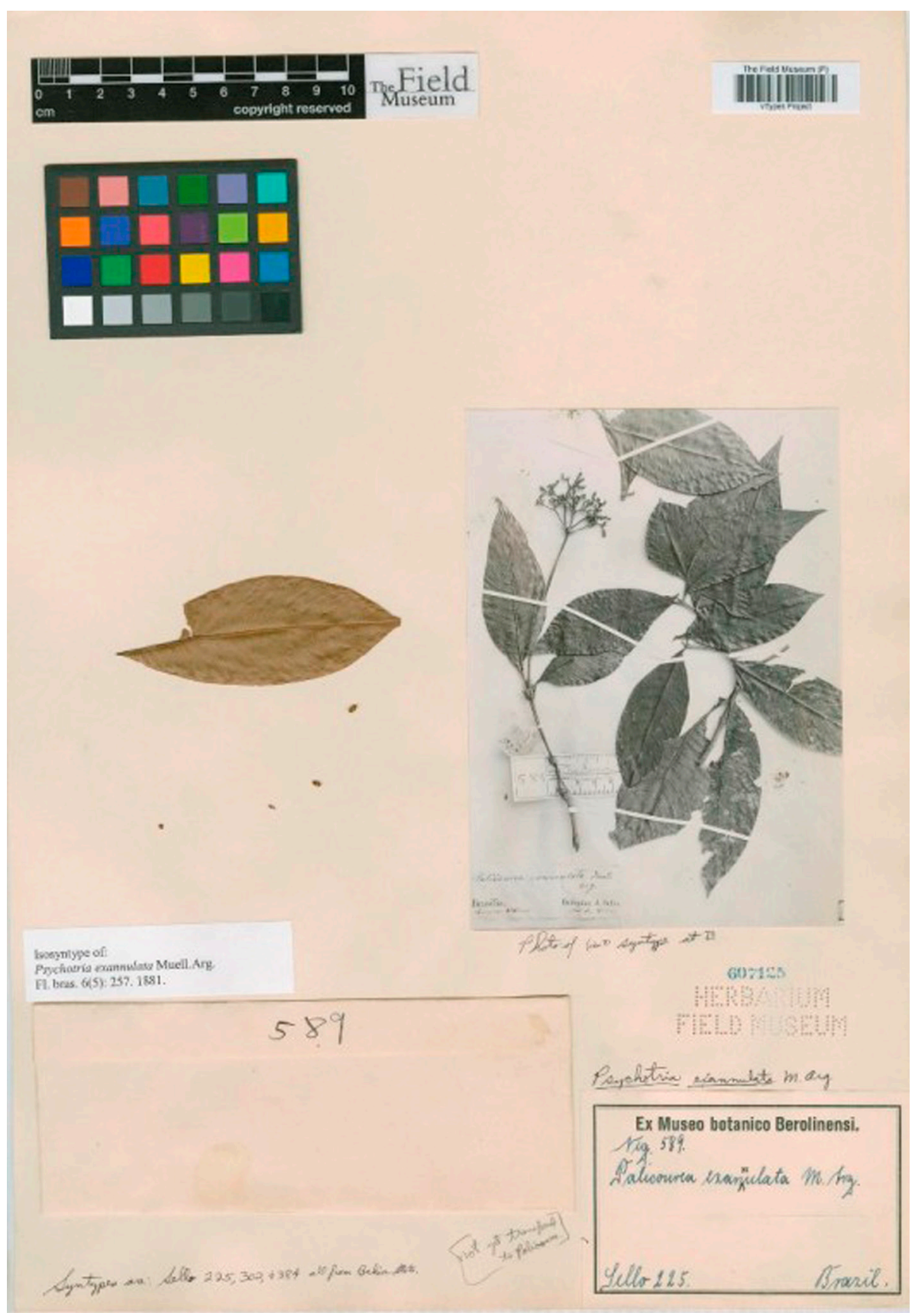

Fig. 2. Syntype of Psychotria exannulata Müll. Arg. (F 607125).

taxa showed that the shape of the inflorescence has a great plasticity. Its shape overlaps and ranges from umbel to cor$\mathrm{ymb}$, with a continuum of intermediate forms. Fieldwork also showed that the extremes of this variation are not associated to their geographic distribution. Thus, since the two species proposed by Johannes Müller Argoviensis do not differ significantly in the remaining characters, we propose they be treated as a single species, Palicourea fulgens.

\section{ACKNOWLEDGEMENTS}

The authors are grateful to the Plant Biology Post Graduation Program at Universidade do Estado do Rio de Janeiro and Javier Fuertes for their contributions to this text. The first author received financial support from the Coordenação de Aperfeiçoamento de Pessoal de Nível Superior (CAPES).

\section{REFERENCES}

McNeill, J., Barrie, F.R., Buck, W.R., Demoulin, V., Greuter, W., Hawksworth, D.L., Herendeen, P.S., Knapp, S., Marhold, K, Prado, J., Prud'homme van Reine, W.F., Smith, G.F., Wiersema, J.H. \& Turland, N.J. (eds.). 2012. International Code of Nomenclature for Algae, Fungi, and Plants (Melbourne Code). Regnum Vegetabile. 154.

Müller, J. 1881. Psychotria. In: Martius, C.F.P., Eichler, A. W. \& Urban, I., Flora Brasiliensis 6(5): 463. Leipzig.

Taylor, C.M. 1997. Conspectus of the genus Palicourea (Rubiaceae: Psychotrieae) with the description of some new species from Ecuador and Colombia. Annals of the Missouri Botanical Garden 84(2): 224-262. http://dx.doi.org/10.2307/2400003 
Taylor, C.M. \& Steyermark, J.A. 2004. Palicourea Aubl. In: Berry, P.E., Yatskievych, K. \& Holst, B.K., Flora of the Venezuelan Guayana, vol. 8: 680-694. Missouri Botanical Garden Press.

Urban, I. 1906. Vitae itineraque collectorum botanicorum, notae collaboratum biographicae, flora brasiliensis ratio edendi chronologica, systema, index familiarum. In: Martius, C.F.P., Eichler, A.G. \& Urbano, I., Flora Brasiliensis 1(1): 27-28, 105-111. Munich.
Zappi, D.C. \& Taylor, C. 2014. Palicourea. In: Campostrini, R., Zappi, D., \& Castro Souza, V. (coords.), Lista de Espécies da Flora do Brasil. Jardim Botânico do Rio de Janeiro. http://floradobrasil.jbrj.gov.br/2010/FB014133.

Associate Editor: Javier Fuertes Received: 26-VI-2014 Accepted: 7-IV-2016 